\title{
GIOLOGICAL SETTING AROUND THE HEADS OF THE TRINCOMALEE CANYON, SRI LANKA
}

\author{
N. P. WIJAYANANDA \\ Oceanograpby Unit, National Aquatic Resources Agency, Colombo 15, Sri Lanka.
}

(Date of receipt : O9 October 1985)

(Date of acceptance : 30 January 1986)

\begin{abstract}
Detailed geological mapping was undertaken in the land around the heads of the Trincomalee Canyon, in an attempt to determine its probable origin. This Canyon is in alignment with the Mahaweli shear zone. It has the trend similar to the general strike of the country rocks and has three principal heads, one at the Trincomalee inner harbour and two at the Koddiyar Bay. The head at the inner harbour and the one south east of the bay probably follow a fracture zone. The River Mahaweli has played a major role in forming the two main heads and the sub-heads at the Koddiyar Bay. The survey reveals that the shape of the Canyon heads are controlled by the geology of the area.
\end{abstract}

\section{Introduction}

In 1908, Somerville first noted several deep and narrow notches in the submarine plateau off the east coast of Sri Lanka. ${ }^{1}$ The Trincomalee harbour is in one of these and during the two World Wars this harbour was of immense interest as it was found to be an extraordinarily deep canyon. Several workers studied it at different times $2,5,6,7$ and confirmed it to be a large submarine canyon.

The canyon has three main heads and these heads have cut into the land. The Trincomalee inner harbour is in one and Koddiyar Bay is in the other two heads (Figures 2,5 and 6). Thus, since the land surrounds all these heads, this situation was found to be ideal to study the geology around the canyon heads. A detailed geological mapping programme was carried out in the area around the heads of the Trincomalee Canyon and an attempt was made to find whether the development of the canyon heads are geologically controlled.

Geological mapping was undertaken using air photographs including mosaics from the Survey Department of Sri Lanka. Air photos (scale 1:20,000 - 1984 air surveys) mosaics (scale ' 2 inches = 1 mile' - 1956) were available for the entire area. All geological data were transferred to the mosaics for the preparation of the final geological map of the area. 
This work was carried out as a part of the Trincomalee Canyon study programme conducted by the National Aquatic Resources Agency.

\section{Physiography}

The Trincomalee Canyon has a length of $40+\mathrm{km}$ with an average slope of about $1 / 18$ or $3^{\circ}$. The volume of the canyon was computed as the material missing from the continental margin and is approximately $1000 \mathrm{~km}^{3}$. The general trend of the canyon axis is north east - south west.

Three principal heads were identified, two at the Koddiyar Bay and one at the inner harbour (Figure 2). The narrow outer shelf trough formed by the headward bifurcation of the main canyon axis forms the head at the Trincomalee inner harbour. The other bifurcations form two heads at the Koddiyar Bay.

The axis of the main head at the Koddiyar Bay trends north-east for about $6 \mathrm{~km}$ with a slope of $1 / 7$ or $8^{\circ}$ and at a depth of $600 \mathrm{~m}$. it bends $90^{\circ}$ to north-west for a distance of about $3 \mathrm{~km}$ with a gentle slope of $1 / 30$ and again turns $90^{\circ}$ back to north-east at a depth of $700 \mathrm{~m}$ (Figure 2). The axis again runs north-east for about six $\mathrm{km}$ at a slope of about $4^{\circ}$ or $1 / 15$ and then turns north-north-east at a depth of $1500 \mathrm{~m}$. As it goes further on the continental slope the canyon turns gradually to north-east, and thereafter broadens and debounches on the continental rise at a depth of about $3400 \mathrm{~m}$. The two other heads of the canyon project landwards and trend in a north west-south east direction and are only $50 \mathrm{~m}$ deep.

\section{General Geology}

More than $90 \%$ of the island of Sri Lanka is underlain by Precambrian metasedimentary rocks which are grouped into two major lithological zones - the Highland Series and the Vijayan Series (Figure 1). Within the Highland Series a subdivision of the south-west group has been identified. ${ }^{3}$ The Vijayan Series is geographically divided into the Eastern and Western Vijayan.

The Highland Series is composed, predominantly of granulite facies rocks. the main rock types being charnockites and their variants, quartzites, marbies and varieties of metasedimentary gneisses. The Vijayan Series consists of homblende biotite gneisses, migmatites, granites and granitic gneisses of the amphibolite facies. The south-west group is characterized by calc-gneisses, calc-granulites, wollastonite-bearing calciphyres and cordieritebearing gneisses with sillimanite. 


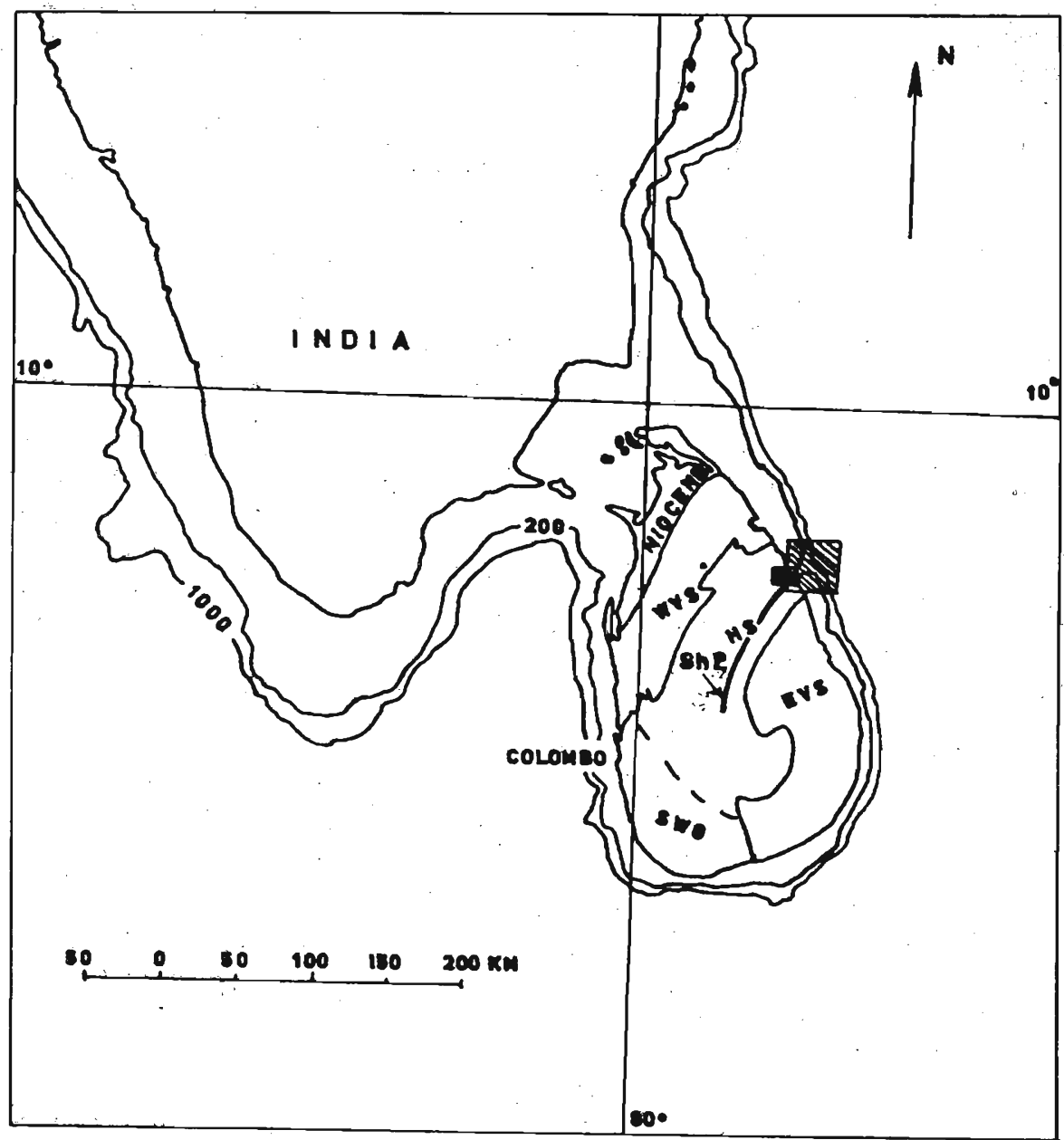

Figure 1. Outline geological map of Sri Lanka showing the study areas (shaded and ctoss-hatched)

H.S. $\quad-$ Highland Series

W.V.S. - Western Vijayan Series

E.V.S. - Eastern Vijayan Series

S.W.G. - South West Group 


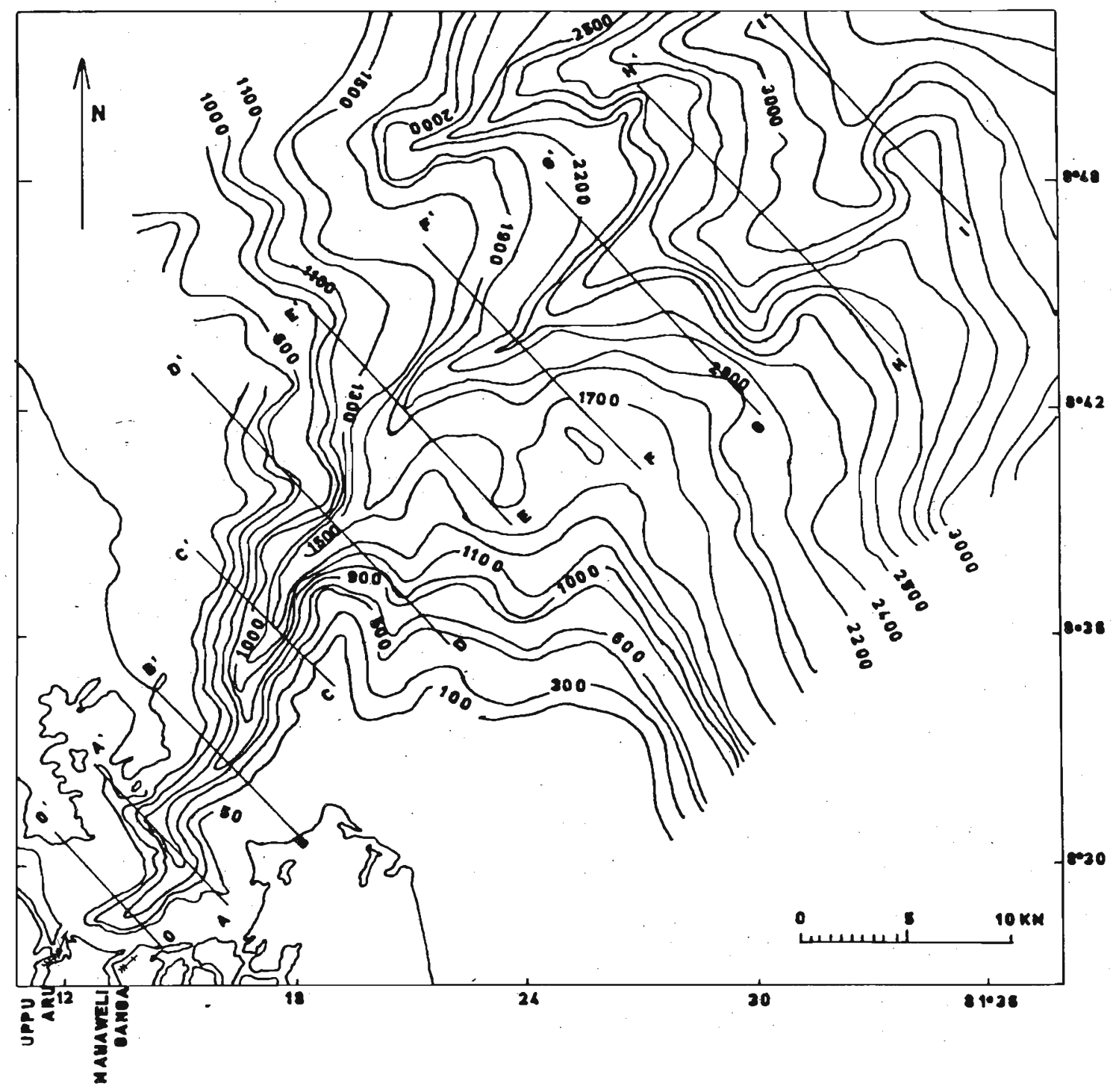

Figure 2. Bathymetric chart (in metres) of the Trincomalee Canyon. Shaded area of Figure 1 (Stewart et al. 1964b). 

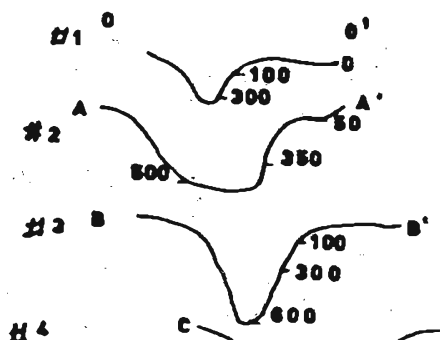

4
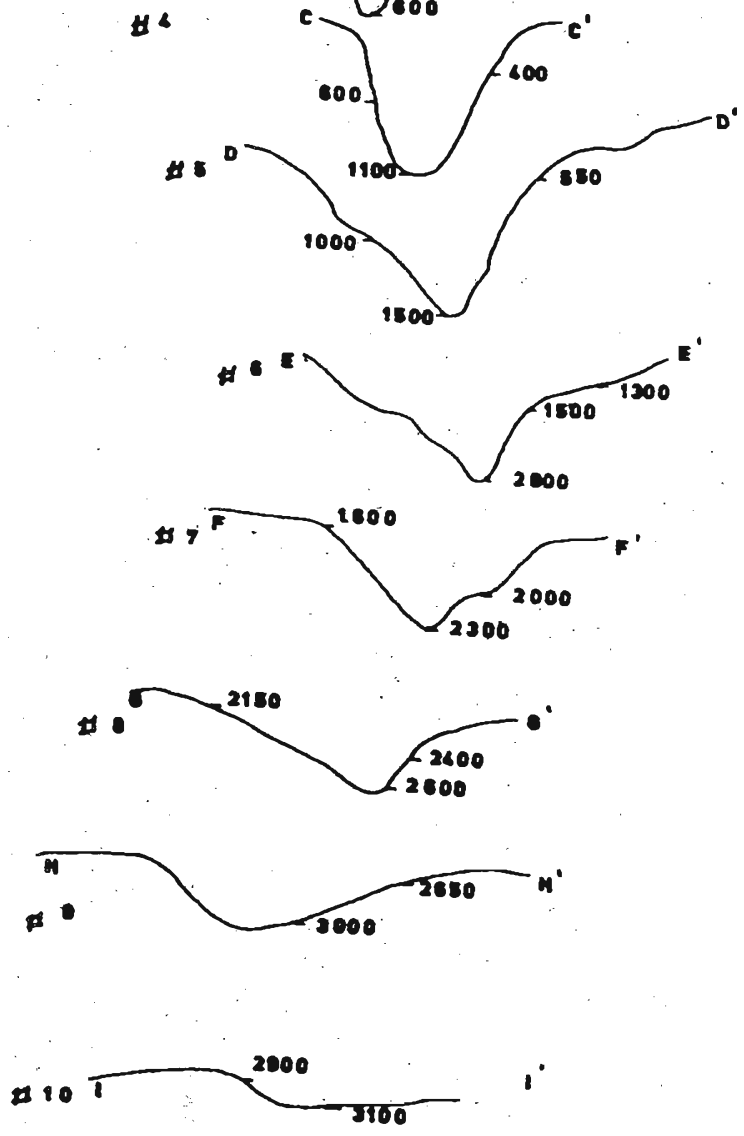

Figure 3. Transverse profiles of the Trincomalee Canyon. Profiles oriented to face down Canyon. For location see Figure 2. Vertical exageration x 5.8. Depth in metres. 


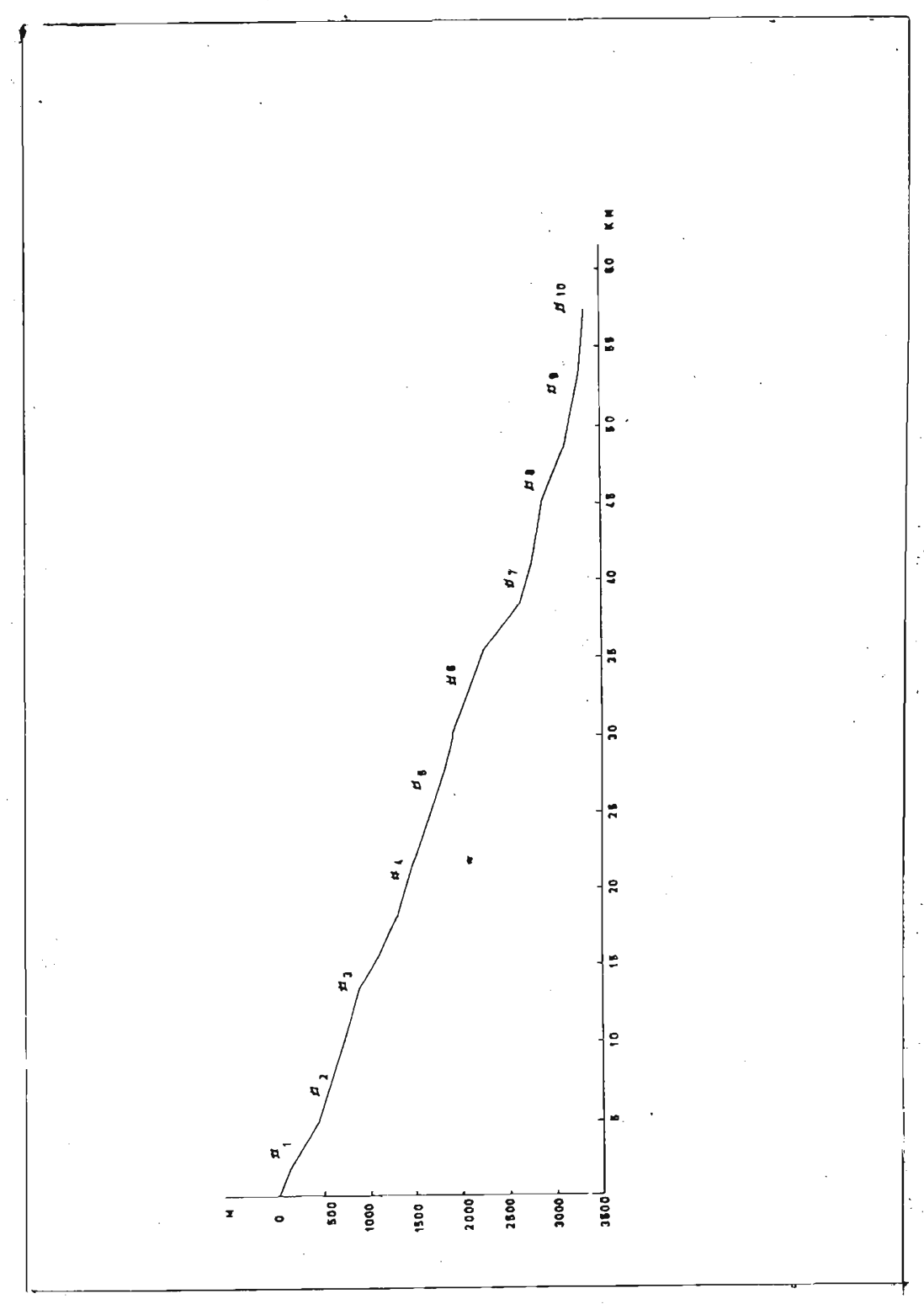

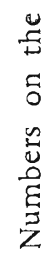

¿่̊

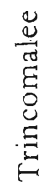

4

永

동

苛

员江

苞苕

蛋

焉昰

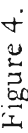


The area studied falls under the Highland Series group of rocks (Figure 1) and is covered by the one inch to one mile Trincomalee topographic sheet. Quartzite is the most prominent rock in the area and is also the most resistive rock type to weathering. All the ridges in the inner harbour are composed of quartzites and most of the bays have formed in between these bands. Charnockite is the interbanded rock with the quartzite. Though charnockite is a more resistive rock in the interior of the island, at the harbour area, charnockite has eroded faster than the quartzite. Most of the bays as Nicholson's Cove, Malay Cove, Minden Cove, Deadman's Cove are formed due to the quicker erosion of the charnockites. The southeast of Koddiyar Bay is mainly charnockite. Three prominent bands of impure marbles were found in the area. One band lies in the valley bottom of the Petroleum Corporation Upper Tank Farm area and runs below the China Bay railway station into the inner harbour at Harden Point. This marble band is in alignment with the sharp demarcated Yard Cove, but no exposures were seen beyond Harden Point. Though no outcrops were found in the south west extension of this marble band, morphologically it is evident that the band runs into the Thambalagam Bay, between the 177 and $1771 / 2$ mile posts of the railway line. Remnants of another similar band is found at Marble Beach in the south-east valley of the Diamond Hill ridge. The other prominent marble band was south east end of the study area near the Ulackalie lagoon (Figure 5).

Thin elongated patches of marble are also found at several places. They are located as follows: (a) near the sea, down the south-east slope of the ridge at the Ceylon Fishery Harbour Corporation (Cod Bay) new circuit bungalow, (b) near the junction of the turn to the China Bay from the Trincomalee - Dambulla road, and (c) a few metres thick patch at the southwest bay of the Periyakulam ridge.

A pink feldspar granulitic gneiss is present north of the inner harbour. This is a very prominent rock in the north of the study area, but is not found around the harbour. This granulitic gneiss has charnockitic and basic layers interbanded and is migmatitic at certain places. These features are well exposed at the quarries between the 108 and 109 mile posts of the Anuradhapura - Trincomalee road. Four prominent garnet-biotite-gneiss bands were present, two in the north west and two in the south east of the study area. The shape of the land north of Sampur (Figure 5) and the garnetbiotite-gneiss and chamockite lithology clearly shows that the differential weathering and erosion has contributed to the form of it. The garnet-biotitegneiss band near Ullakulam (Figure 5) is not traceable due to the lack of fresh outcrops and at some leached outcrops it is difficult to distinguish garnet-biotite-gneiss and charnockite. A coarse grained scapolite-diopside rock is found at the old quarry near the Ceylon Fishery Harbour Corporation, Cod Bay circuit bungalow. Several fine grained porphyritic basalt dykes were observed near this coarse grained rock and they are closer to the 


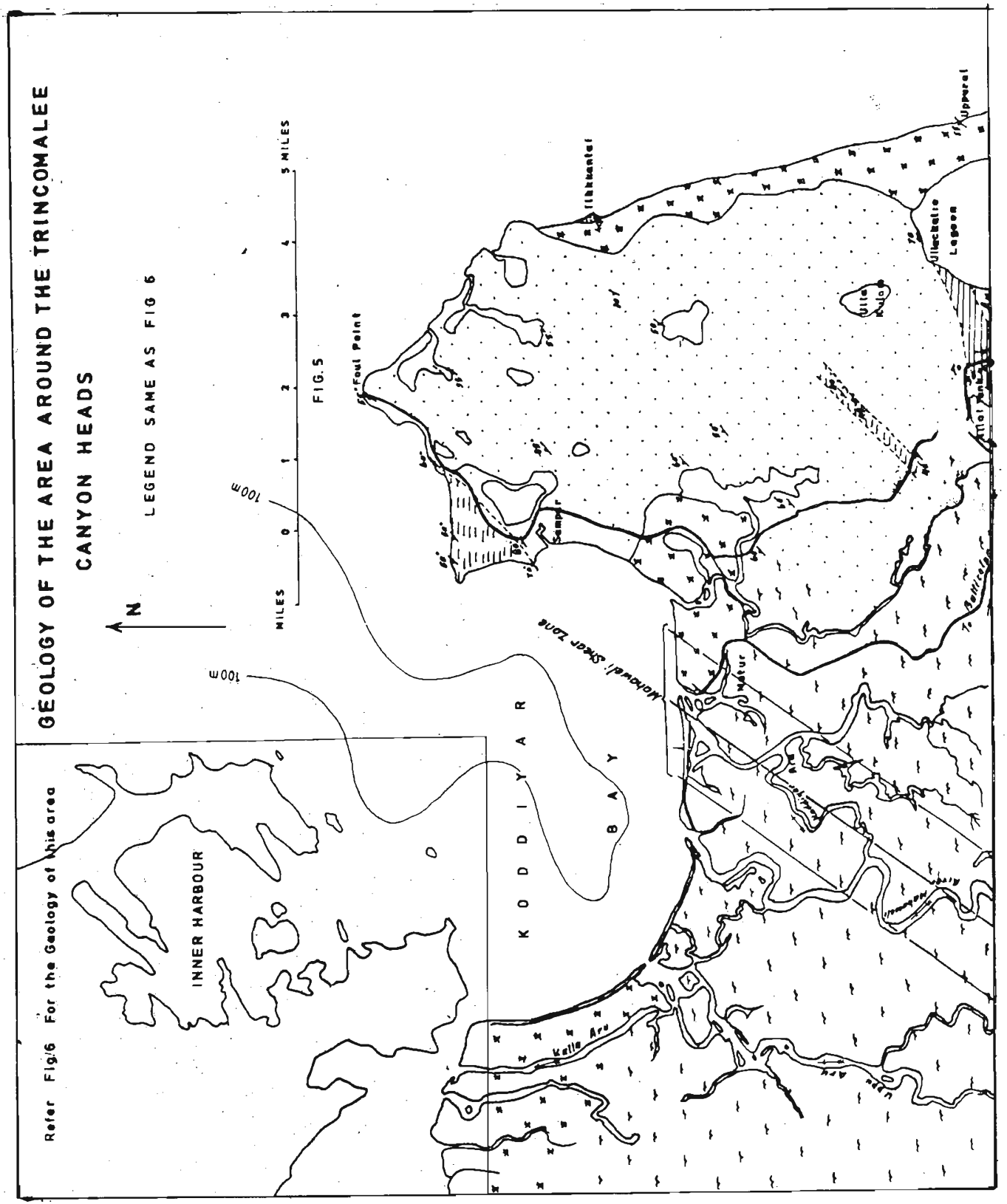

Figure 5. Geology of the area around the Trincomalee Canyon heads. 
Sri Lanka Port Authority jetty. Similar dykes of few metres thick have also been observed in the north coast of the Great Sober Island. A traceable anorthosite band is present at the south end of the study area near Ullackalie Lagoon (Figure 5). The area covering from Mutur to Tambalagam Bay is the Mahaweli flood plain and is the land next to the two canyon heads at Koddiyar Bay. This area is covered with recent alluvial deposits (Figure 5).

\section{Structure}

The aerial photographs of the area covering the coastal belt from Seruwila up to Nilaweli on the scale of $1: 20,000$ and 1:40,000 were studied for the preliminary structural investigations. The mega-scale structures observed in the air photo interpretation were confirmed in the field mapping, and a few more medium to small scale structures were identified. The area is characterized by south-westerly plunging antiforms, a synform and steeply dipping basin ("arena").

The two ridges at the Navy premises on either side of the Nicholson's Cove are limbs of the southernmost antiform with the axis running right across the Dutch Point. This is an assymetrical antiform. The axis of the adjoining synform falls across the Great Sober Island and the Trincomalee town. The nose of it is closer to the Fort Fredrick. The axis of the other antiform is through China Bay. A steeply dipping basin ("arena") is found north west of the area. The pink feldspar granulitic gneiss, the core rock of this "arena" dips almost vertically. The above structural features do not show much influence on the formation of the canyon. Two major faults are located across the two small bays at the Cod Bay. One runs across Palaiyuttu and displaces the quartzite ridge north of it. The other fault is through Tekiluttu and displaces the same ridge at another location. These faults have directly influenced the opening up of Cod Bay (Figure 6).

The south east part of the area is of uniform dip at an average $50^{\circ}$ north west. Minor flexures were seen in abundance at most of the large outcrops (Figure 5).

\section{Discussion}

With the limited data available it is rather difficult to draw definite conclusions on the genesis of the Trincomalee Canyon. It is, however, evident that several factors have contributed to its formation. If the $100 \mathrm{~m}$ contour line is considered as the sea level during the ice age (17,000 years ago), the landward end of the Trincomalee Canyon would have been very simple at that time, with only one principal head. 


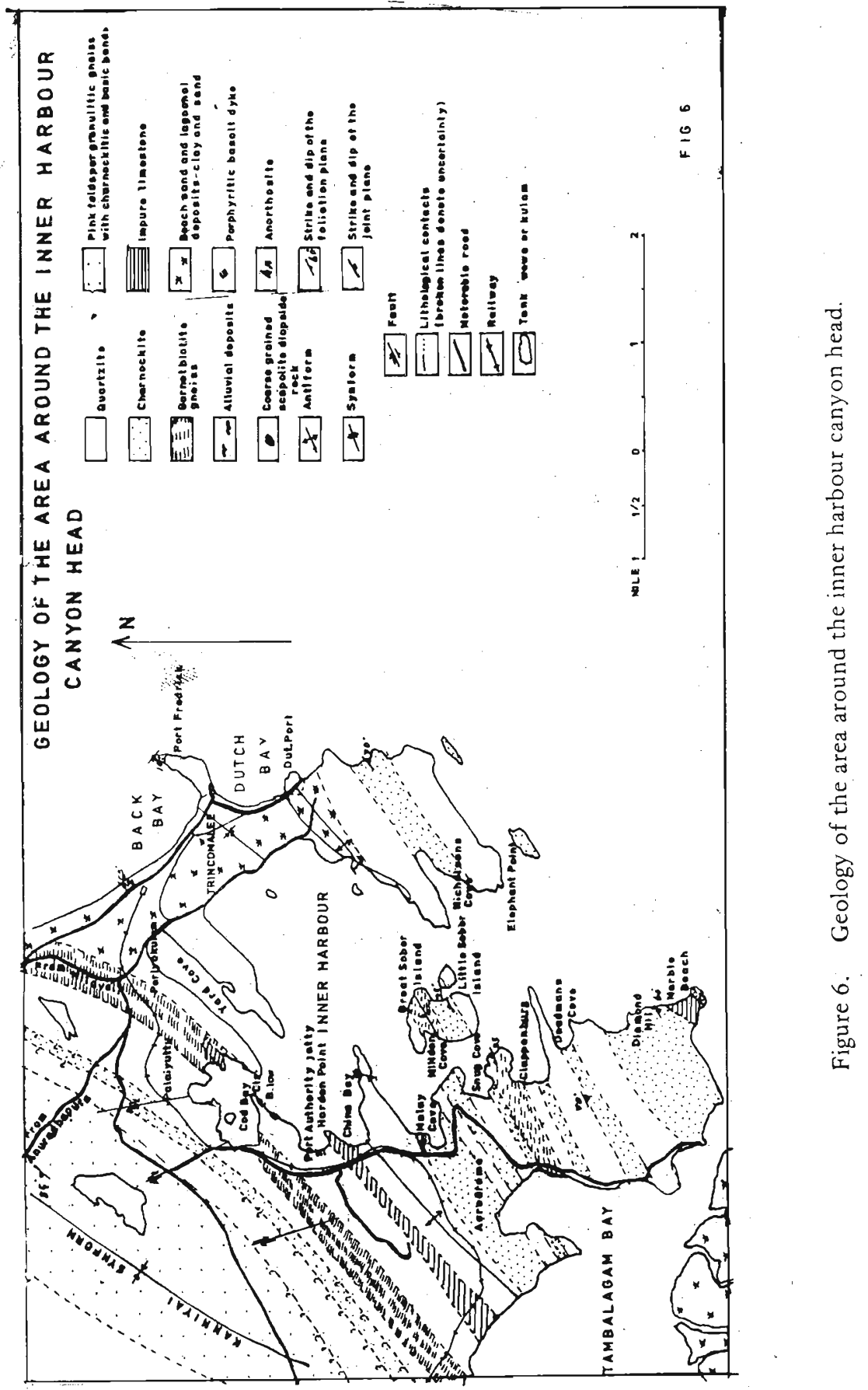


Several small canyons are also found in the continental shelf of Sri Lanka. Some of these are located off the main river valleys but only at Trincomalee do the canyon heads come within $600 \mathrm{ft}$ of the shore. ${ }^{6}$ Uppu Aru which is in the flood plane of the Mahaweli River has its mouth where the head of the canyon begins (Figure 2). It is reasonable to assume that during the ice age the Mahaweli waters moved into the canyon through Uppu Aru and it is interesting to note that even at present these two rivers are connected. ${ }^{4}$

Vithanage ${ }^{8}$ has reported that the geological mapping of the eastern section of the Polonnaruwa sheet (near Gallella) shows that the Mahaweli lineament follows a $\mathrm{N}-\mathrm{S}$ shear zone along a calc-gneiss band and probably continues $\mathrm{N}-\mathrm{E}$ to Trincomalee where a series of deep submarine canyons have been located. Vithanage ${ }^{9}$ observed that the River Mahaweli and the Trincomalee Canyon are in the Mahaweli Shear zone. The Mahaweli shear zone could therefore be a contributing factor to the formation of the Trincomalee canyon. Except for the principal axial head of the canyon, all the other heads lie above the $100 \mathrm{~m}$ contour line. The formation of the inner harbour head and the second head at the Koddiyar Bay have undoubtedly developed after the ice age.

Bush and Bush ${ }^{2}$ suggest the sharp bend of the canyon in Koddiyar Bay could be due to a fault zone. Such a fault zone could also have given rise to the inner harbour head and the second head in Koddiyar Bay. During the ice age the inner harbour area may have had the normal ridge valley topography as we find in the present day land. With the rise in the sea level the inner harbour area has got submerged gradually and the present bays have opened up rapidly due to wave and current actions. All the ridges around the inner harbour are made up of quartzites and the valleys are charnockites, marble and gneisses. The present day bays have formed in valleys of the ice age and are due mainly to differential erosion. The probable fault suggested by Bush and Bush ${ }^{2}$ falls across the Cod Bay. Two other faults have also been identified which cut across Cod Bay and northwest openings of the Cod Bay are due to these faults.

The inner harbour opens up in two directions and the carving parallel to the general trend of the area is due to differential erosion and that oblique to the trend line is along fracture planes. These forms have developed due to the structure and lithology of the area around the inner harbour.

It has been observed that another canyon head is developing at the mouth of the Mahaweli River (Figure 2). Taking into consideration that the Mahaweli was connected to Uppu Aru during the Ice Age and recently changed its position, it is evident that the river has played a major role in the formation of the small canyon head at its present mouth. This shows that the Mahaweli River also has influenced the form and the development of the canyon. 


\section{Conclusions}

The recent geological mapping done in the land around the Trincomalee Canyon shows that the form of the inner harbour head is structurally and lithologically controlled. The River Mahaweli has played a major role in the formation of the principal axial head of the canyon. Another axial head is developing at the mouth of the present Mahaweli River. As suggested by Bush and Bush ${ }^{2}$ it is possible that the sharp bend in the canyon valley, inner harbour head and the second head at the Koddiyar Bay is due to a probable fault zone.

\section{Acknowledgements}

Dr. W. S. Wickramaratne helped by mapping a part of the study area. Messrs. S. R. Amaratunge and Danton Silva assisted in the field. The Director, Geological Survey Department of Sri Lanka made their unpublished Trincomalee and Nilaveli reconnaisance geological maps available for this study. Grateful thanks are due to Dr. M. M. J. W. Herath for his valuable suggestions. This paper is published with the kind permission of the Chairman of the National Aquatic Resources Agency, Colombo.

\section{References}

1. ADAMS, F. D. (1929 a). The geology of Ceylon, Can. J. Res. 5, 425-465.

2. BUSH, S. A. \& BUSH, P. A. (1969). Trincomalee and associated canyons, Ceylon Deep-sea Research, $16: 655-660$.

3. COORAY, P. G. (1978).Geology of Sri Lanka Precambrian. In: P. Nalaya (Editor), Proc. 3rd Reg. Conf. on Geol. and Miner Resources of S.E. Asia. Asian Inst. of Technology, Bangkok, Thailand, 701-710.

4. FERNANDO, A. D. N. (1982-83). Geomorphology and the hydraulic civilization of Sri Lanka. In: I.T.C. Journal 1982-83, special issue honouring Herman Th Verstappen. I.T.C., publications, Enschede, The Netherlands, 356-361.

5. SHEPARD, F. P. (1963). Submarine canyons, In: The Sea. M.N. Hill, ed. Wiley, New York, 480-506.

6. SHEPARD, F. P. \& DILL, R. F. (1966).Submarine canyons and other sea valleys, Rand Mc Nally \& Co., Chicago, 203-206. 
7. STEWART, H. B. Jr., SHEPARD, F. P. \& DIET'L, R. S. (1964).Submarine canyons off eastern Ceylon. Abs. Ann. meeting, Geol. soc. Am., 197.

8. VITANAGE, P. W. (1972). Post Precambrian uplifts and regional neotectonic movements in Ceylon, 24th I.G.C., Sec.3.

9. VITANAGE, P. W. (1985). The Geology, structure and tectonics of Sri Lanka and South India. Recent Advances in the Geology of Sri Lanka. CIFEG occasional publication No. 6 (1985). Paris, France, 5 - 15. 